\title{
INTENSIFICATION OF FLEXURAL STRENGTH OF LIGHTWEIGHT FOAMED CONCRETE VIA WOVEN FIBERGLASS MESH CONFINEMENT
}

\author{
ANISAH MAT SERUDIN, MD AZREE OTHUMAN MYDIN \& ABDUL NASER ABDUL GHANI
}

School of Housing, Building and Planning, UniversitiSains Malaysia, 11800, Penang, Malaysia

\begin{abstract}
LFC possesses brittleness behaviour where its strength very poor and weak compared to normal concrete. However, due to its advantages, many researchers eager to find a new method or solution to enhance the strength of LFC. Even though, the LFC gain improvement but still there are side effects that has been faced. Thus, invention of textile fabric as reinforcing elements shows its potential use to boost the strength of LFC. Three different densities were designed which were $600 \mathrm{~kg} / \mathrm{m}^{3}, 1100 \mathrm{~kg} / \mathrm{m}^{3}$, and $1600 \mathrm{~kg} / \mathrm{m}^{3}$ with fixed mix ratio, 1:1.5 for cement-to-sand ratio, and constant water at 0.45. Woven fiberglass mesh $\left(160 \mathrm{~g} / \mathrm{m}^{2}\right)$ was utilized as confinement of LFC specimen with different number of layer(s) employed. Based on the results obtained, a confinement of 3 layers of woven fiberglass mesh showed significant results where the flexural strength of LFC gain enhancements of $372 \%\left(600 \mathrm{~kg} / \mathrm{m}^{3}\right), 258 \%\left(1100 \mathrm{~kg} / \mathrm{m}^{3}\right), \mathrm{and}_{332 \%}\left(1600 \mathrm{~kg} / \mathrm{m}^{3}\right)$ compared to the control $\mathrm{LFC}$.
\end{abstract}

KEYWORDS: Foamed Concrete, Flexural Strength, Textile Fabric, Fiberglass Mesh, Confinement

Received: Jun 08, 2020; Accepted: Jun 28, 2020; Published: Aug 29, 2020; Paper Id.: IJMPERDJUN2020961

\section{INTRODUCTION}

The inclusion of natural fibres in LFC has been widely investigated. The strength of LFC is significantly increased by the addition of natural fibres in the cement matrix. However, the fibres only enhance the strength of the concrete at an early age, and this strength will start to decrease at a later curing age. Wei and Meyer (2016) stated in their report that the main reason for this is the deterioration of the fibres in the concrete, where the fibres suffer degradation in the highly alkaline cement paste (Portland cement). Abdulameer (2015) also added that the highalkaline environment dissolves the lining and hemicellulose phase of the fibres, thus weakening the natural structure of the fibres.

Nevertheless, many studies were also conducted previously using synthetic fibres. In 1996, Banthia and Sheng clarified that the addition of steel, polypropylene and carbon fibres can overcome the brittle properties of concrete. Kayali et al. (2003) also stated in their study that the addition of $0.56 \%$ by volume of polypropylene fibres indirectly caused an increase of $90 \%$ in the tensile strength and $20 \%$ in the modulus of rupture of lightweight aggregate concrete. This was followed by a research conducted by Chen and Liu in 2005, in which they also verified that the addition of steel fibres not only increased the splitting tensile strength of expanded polystyrene concrete but also improved its resistance to shrinkage. Besides, Ibrahim et al. (2014) also mentioned that the compressive strength of LFC improved only slightly with the addition of polyolefin fibres, where the compressive strength of the control specimen was $7.4 \mathrm{~N} / \mathrm{mm}^{2}$ while the compressive strength of LFC was only $7.8 \mathrm{~N} / \mathrm{mm}^{2} \mathrm{on}$ day-28 following the addition of $0.4 \%$ fibre. 
Although all the mentioned studies were conducted to improve the durability and mechanical properties of LFC, there are still drawbacks to the use of these materials. In 2013, Olaoye et al. discovered that the major problem with using reinforcing elements like steel in concrete is the corrosion of the material, which clearly disrupts the lifespan and robustness of the concrete structure. Besides, Alberti et al. (2014) also found that although a good performance is obtained by the combination of steel in a concrete structure, its shortcomings range from corrosion to high purchase, storage and handling costs. Amran et al. (2015) also reported that the utilization of steel fibres in LFC is not appropriate due to their heavy weight, which causes them to settle at the bottom of the concrete mixture. Hence, this research project was performed to explore the potential use of woven fiberglass mesh reinforced LFC as a construction material. Woven fiberglass mesh is a textile fabric that is widely used in normal concrete, also known as Textile Reinforced Concrete (TRC). It is an alkali-resistant material that can be used to replace the reinforcing steel in LFC.

\section{LITERATURE REVIEW}

Based on a study by Dawood and Hamad (2015), plain concrete is a brittle material which has poor fracture toughness, weak resistance to crack propagation, and low impact strength. These characteristics, which cannot sustain the tensile stress due to the zero applied force in the tensile zone, tend to restrict its applications. However, Jones and McCarthy (2005)explained that LFC can still be used as a structural material. According to the research conducted by Narayanan and Ramamurthy (2000), the flexural strength of LFC ranges between $15 \%$ to $35 \%$ of its axial compressive strength. Besides, Kozłowski and Kadela (2018) discovered that the flexural strength of LFC can be increased by increasing its density as the apparent density of hardened LFC is strongly associated with the foam content in the mix.

Several studies have been carried out on the flexural behaviour of cementitious composites reinforced with textile fabrics. Peled et al. (1999) found that there was an improvement in the flexural strength of the composite due to the textile fabric reinforcement, which was achieved even when low-modulus synthetic fibres were used. According to Dalal et al. (2017), textile fabrics resist and improve the ductility of concrete, thereby retarding cracks in the matrix and transferring loads to allow the development of a microcrack distribution system. Besides, Vogel et al. (2016) also discovered that glass fibre textile reinforcements (textile fabrics) in concrete have greater resistance to impact loading compared to unreinforced concrete.

Moreover, Chi and Louda (2019) investigated the flexural behaviour of geopolymer composite specimens made of textile reinforced geopolymer mortar reinforced with basalt and carbon mesh (with different aperture sizes). The results showed that the basalt meshes with three types of aperture sizes had no significant impact on the flexural strength of the composite as compared to the control specimen without reinforcement, while the carbon meshes had a significant impact, and the composite specimens with smaller mesh sizes had a stronger flexural strength than those with a bigger mesh size due to the greater contribution of the yarns in the same given thickness of the specimens.

In addition, the flexural performance of the composite reinforced with textile fabrics increased with increasing textile fabric layers. This statement was verified by Chi et al. (2019), who found that by increasing the textile fabric (basalt) layers in the geopolymer mortar, the mechanical properties of the tested specimens were improved significantly, especially when they were reinforced with small-sized meshes. They explained that these specimens failed because of the localization of the initial crack. 
Therefore, the utilization of textile fabrics as reinforcing elements has a significant impact on composites compared to unreinforced composites. As mentioned above, the mechanical properties of a composite reinforced with textile fabric are influenced by many factors, namely, the type of textile fabric (carbon, glass, basalt, etc.), the number of layers of the textile fabric, and the mesh size of the textile fabric.

\section{SAMPLE PREPARATION, MIX DESIGN AND EXPERIMENTAL PROGRAM}

In this research, three different densities of LFC were cast, $600 \mathrm{~kg} / \mathrm{m}^{3}, 1100 \mathrm{~kg} / \mathrm{m}^{3}$, and $1600 \mathrm{~kg} / \mathrm{m}^{3} .600 \mathrm{~kg} / \mathrm{m}^{3} \mathrm{represent}$ the non-structural material, $1100 \mathrm{~kg} / \mathrm{m}^{3}$ for semi-structural, and $1600 \mathrm{~kg} / \mathrm{m}^{3}$ for structural building element. The mix design for this study was fixed into 1:1.5 for cement-to-sand ratio, while the cement-to-water ratio maintained at 1:0.45.Table 1 shows the mix proportions $\left(\mathrm{kg} / \mathrm{m}^{3}\right)$ used in this study. Besides, the textile fabric utilized in this investigation is $160 \mathrm{~g} / \mathrm{m}^{2}$ woven fiberglass mesh which possesses an alkali resistant behaviour.

Table 1: Mix Proportion

\begin{tabular}{|c|c|c|c|c|c|}
\hline \multirow{2}{*}{ Mix density $\left(\mathbf{k g} / \mathbf{m}^{\mathbf{3}}\right)$} & \multicolumn{2}{|c|}{ Mix ratio } & \multicolumn{3}{c|}{ Mix proportion, $\mathbf{~ g / \mathbf { m } ^ { 3 }}$} \\
\cline { 4 - 6 } & Cement/ sand & Water/ cement & Cement & Sand & Water \\
\hline 600 & \multirow{3}{*}{$1: 1.5$} & \multirow{2}{*}{0.45} & 230 & 345 & 104 \\
\hline 1100 & & & 411 & 616 & 185 \\
\hline 1600 & & & 591 & 887 & 266 \\
\hline
\end{tabular}

The woven fiberglass mesh was embedded in the mortar slurry during casting process. It was laid in a longitudinal direction to the LFC specimen as shown in Fig. 1. This was done using the hand lay-up method, as prescribed in the research conducted by Salimian et al. (2016). First, $2 \mathrm{~mm}$ of the LFC slurry was poured into the mould. Then, the woven fiberglass mesh was placed (refer to Fig. 2), and the remaining LFC material was poured into the mould until reached a depth of $40 \mathrm{~mm}$.

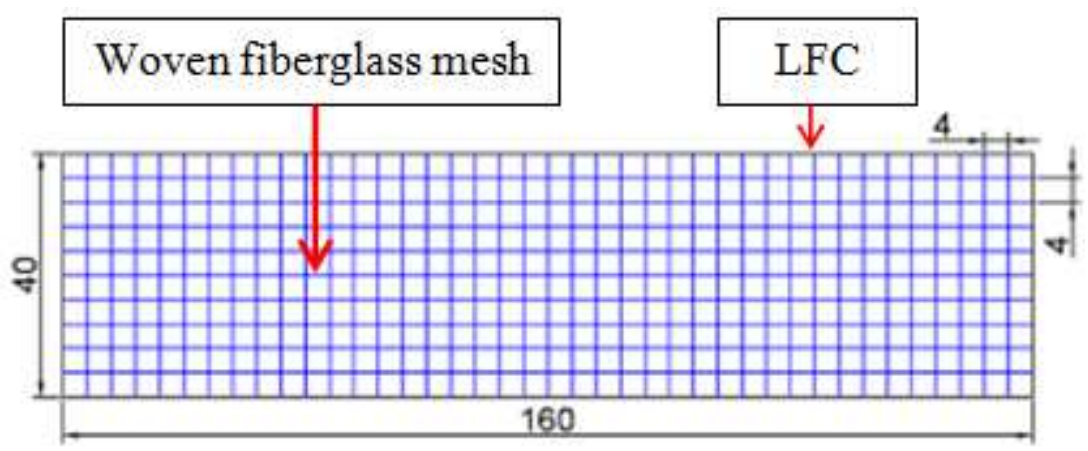

Figure 1: Woven Fiberglass Mesh Laid in a Longitudinal Direction to the LFC Specimen (Top View).

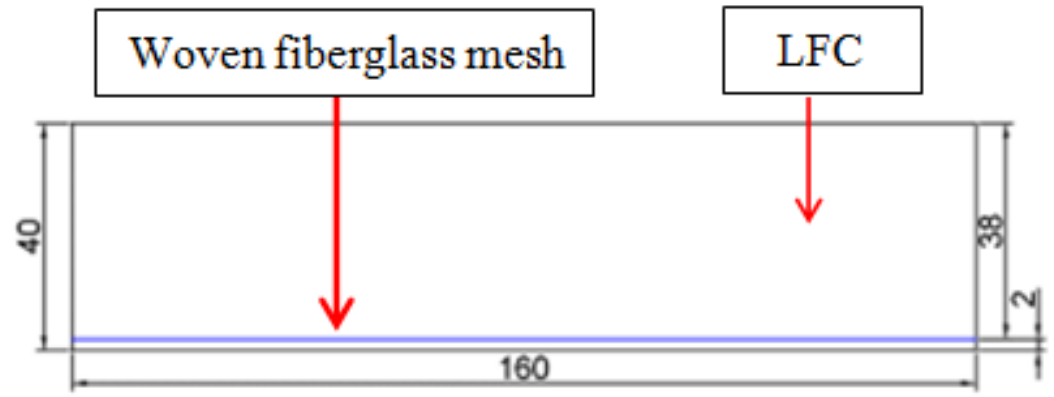

Figure 2: Woven Fiberglass Mesh Placed 2 mm from the Bottom Layer of LFC Specimen (Side View). 
A flexural strength test was conducted using a Universal Testing Machine at a rate of $0.2 \mathrm{~N} / \mathrm{sec}$, as shown in Fig. 3. This test was performed via a three-point bending method, as prescribed in ASTM C348-19 (2004). Three prism specimens measuring $40 \mathrm{~mm}$ x $40 \mathrm{~mm}$ x $160 \mathrm{~mm}$ were used and tested for specified curing periods (7, 28, 56, and 180 days). The flexural strength was calculated using a specified formula (refer to Equation 1), and the average value for the three specimens was recorded. Fig. 3(a) shows the setup for the flexural strength test. This test is very important for identifying the resistance to failure of an unreinforced concrete beam or slab under a flexural load.

$$
\text { Flexuralstrength, } N / \mathrm{mm}^{2}=\frac{3 F L}{2 b d^{2}}
$$

Where, $\quad \mathrm{F}=$ the load at a given point on the load deflection curve $(\mathrm{N})$

$\mathrm{L}=\operatorname{support} \operatorname{span}(\mathrm{mm})$

$\mathrm{b}=$ width of the test sample $(\mathrm{mm})$

$\mathrm{d}=$ depth/thickness of the tested sample $(\mathrm{mm})$

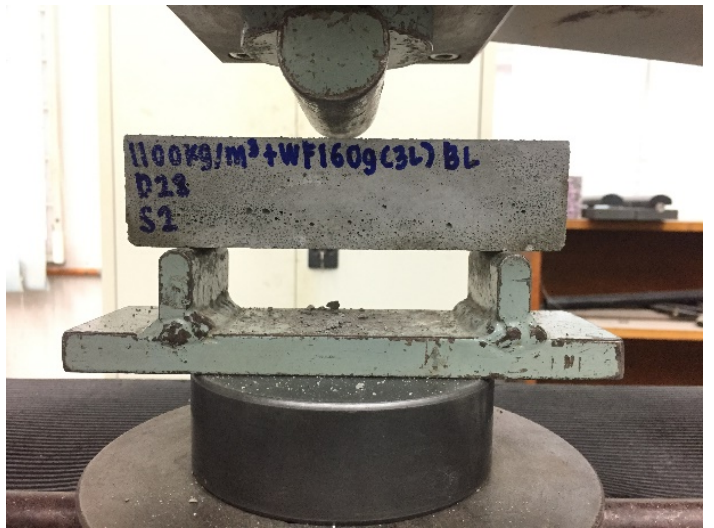

(a)

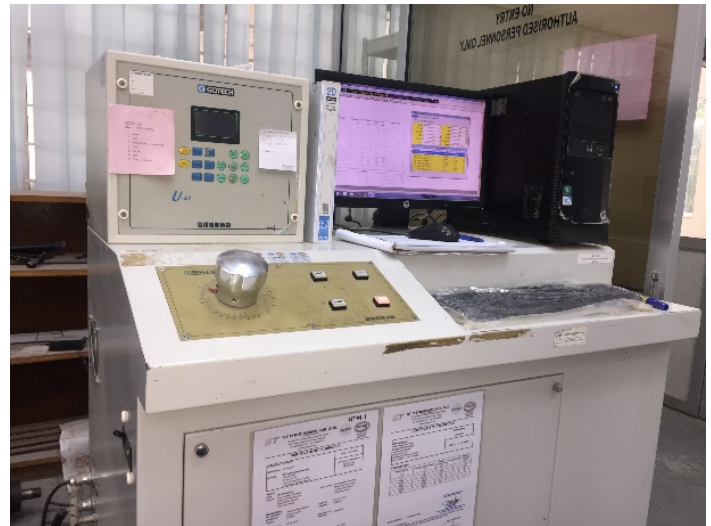

(b)

Figure 3: Setup for Flexural Strength Test for 3 Bending Points.

\section{RESULTS AND DISCUSSION}

Fig. 4, Fig. 5, and Fig. 6 show the flexural strength results for LFC with densities of $600 \mathrm{~kg} / \mathrm{m}^{3}, 1100 \mathrm{~kg} / \mathrm{m}^{3}$, and 1600 $\mathrm{kg} / \mathrm{m}^{3}$. The confined LFC was embedded with 1 layer, 2 layers, and 3 layers of woven fiberglass mesh placed $2 \mathrm{~mm}$ from the bottom layer, while the unconfined (control) specimens did not have any reinforcement in the tensile zone. Based on observations from these three figures, all the specimens gained flexural strength with increasing curing time. The strength development increased steadily for 180 days. Besides, it could be seen that the flexural strength decreased with decreasing density. According to Lian et al. (2011), the strength of concrete is affected by the volume of voids, which is related to the porosity. An increase in porosity reduces the strength of concrete, but the magnitude of this effect depends significantly on the size, shape, and distribution of the pores (Bu \& Tian, 2016). There was a noticeable increase in the flexural strength of the LFC from a density of $600 \mathrm{~kg} / \mathrm{m}^{3}$ to $1600 \mathrm{~kg} / \mathrm{m}^{3}$. As described by Falliano et al. (2019), this occurred as a result of the very low strength values corresponding to the lower densities of LFC. Moreover, it was noticed that the control specimens for the three respective densities displayed very poor flexural behaviour. The reason for this was because the control specimens had zero reinforcement in the tensile zone, where sudden failure occurred as soon as a load was applied. A reinforcement strategy is needed to ensure that LFC with lower densities can be utilized as semi-structural or even more 
advanced structural elements in construction work. Thus, this study investigated the confinement of LFC with a reinforcing element that was subjected to a bending load.

In Fig. 4, 1 layer of woven fiberglass mesh laid $2 \mathrm{~mm}$ from the bottom layer increased the flexural strength of LFC by $136 \%$, but when the number of layers was doubled (2 layers), the flexural strength was boosted by up to $204 \%$, and it was effectively increased by $372 \%$ when 3 layers of textile fabric were added compared to the unreinforced specimens. This trend of increase was also almost the same for the LFC specimens with densities of $1100 \mathrm{~kg} / \mathrm{m}^{3}$ and 1600 $\mathrm{kg} / \mathrm{m}^{3}$ (refer to Table 2). However, as shown in Fig. 5, at day-180, the same flexural strength result for the LFC confined with 1 layer of woven fiberglass mesh could also be obtained at an early age of curing for the specimen confined with 3 layers of textile fabric, and it gained an increase of $258 \%$ compared to the control specimen when it reached 180 days. As expected in Fig. 6, the highest flexural strength among all the specimens was achieved within 180 days by the LFC specimen with a density of $1600 \mathrm{~kg} / \mathrm{m}^{3}$ and embedded with 3 layers of woven fiberglass mesh in the tensile zone of the cement matrix.

The significant increase in the flexural strength of LFC was due to the higher flexibility of the textile fabric, which caused a higher strain in the cement matrix. Naaman (2010) explained that when the cementitious composites crack under bending tension, the reinforcement in the cracked zone will contribute to both stiffness and strength, while the matrix will be cracked. The higher stiffness behaviour of the textile fabric will lead to the debonding of the fibres in the matrix due to the limited release of energy by the textile fabric. Gencoglu and Mobasher (2007) clarified that AR-glass reinforcement provides suitable resistance in impact loading as it absorbs less energy (20-40\% of potential energy). Vogel et al. (2016) also verified in their study that the specimen that had been reinforced with a textile fabric was able transfer more energy to its supports than the unreinforced specimen without the creation of large cracks. This was because the unreinforced specimen absorbed almost double the amount of impact energy (64.03\%) compared to the reinforced specimen, which only absorbed $38.87 \%$ of the impact energy, with the rest of the energy being transferred to the supports.

The structure of the woven fiberglass mesh itself was also the reason for the increase in the flexural strength of the LFC. Basically, a textile fabric is produced by combining several fibres to form a continuous fibre (known as a textile fabric) with a warp and weft structure, either in a coil or a layered fashion (Gayathri et al., 2018). The woven fabric has a crimped geometrical structure, which provides enhanced bonding by mechanical effects (Bentur \& Mindess, 2007). Bentur and Mindess (2007) also explained that the additional enhancement of the bonding of the woven fabric is due to another mechanical anchoring provided by the fill yarns in the weft direction when the fabric is embedded in the cement matrix. Besides, the space between the fibre roving enables some sort of mechanical interlocking to occur between the woven fabric and the matrix, which induces the strength of LFC. This textile fabric is not only able to resist fractures as a consequence of sudden loading, but is also capable of withstanding high fracture toughness with high impact strength. Reddy et al. (2008) also claimed that the good bonding of glass fabric produces higher impact strength. Moreover, Wong et al. (2010) also mentioned that glass fibre is better in terms of both tensile strength and interfacial strength, resulting in the best impact strength compared to natural fibres (such as coir and palm fibres). They also highlighted that increasing the number of layers improves the impact strength. This is because the total surface area of the textile fibre will be increased so that the additional impact energy is dissipated between the fibre layers through extensive delamination. 


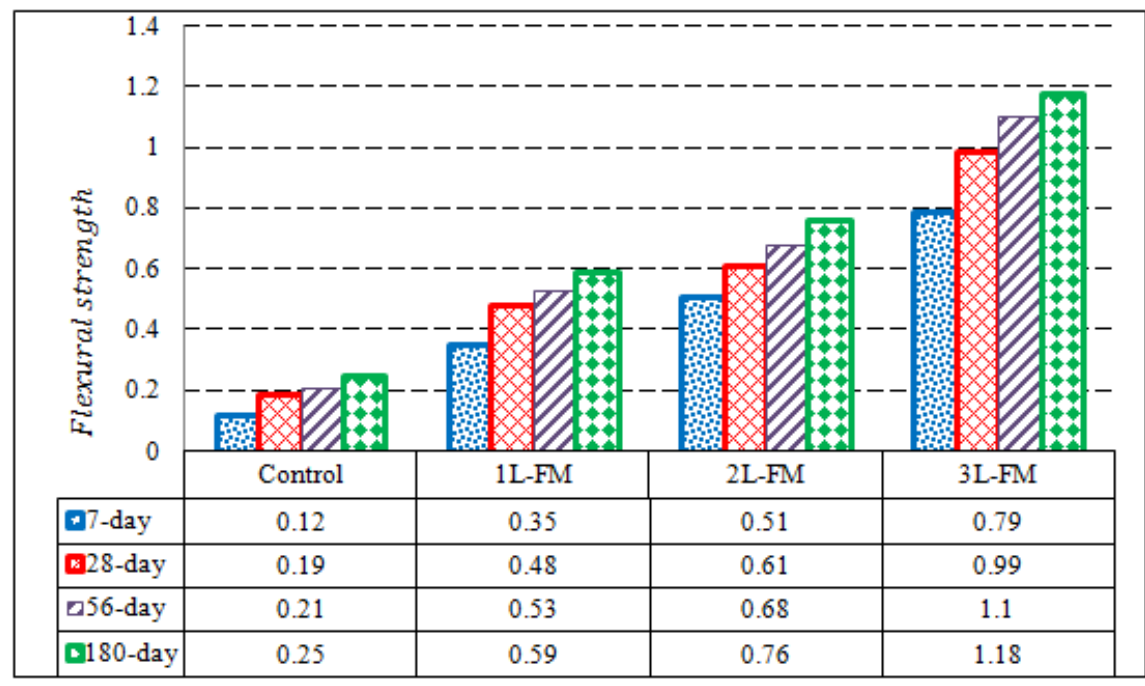

Figure 4: Flexural Strength of LFC Specimens with a Density of $600 \mathrm{~kg} / \mathrm{m}^{3}$ Confined with Different Number of Layers of $160 \mathrm{~g} / \mathrm{m}^{2}$ of Woven Fiberglass Mesh

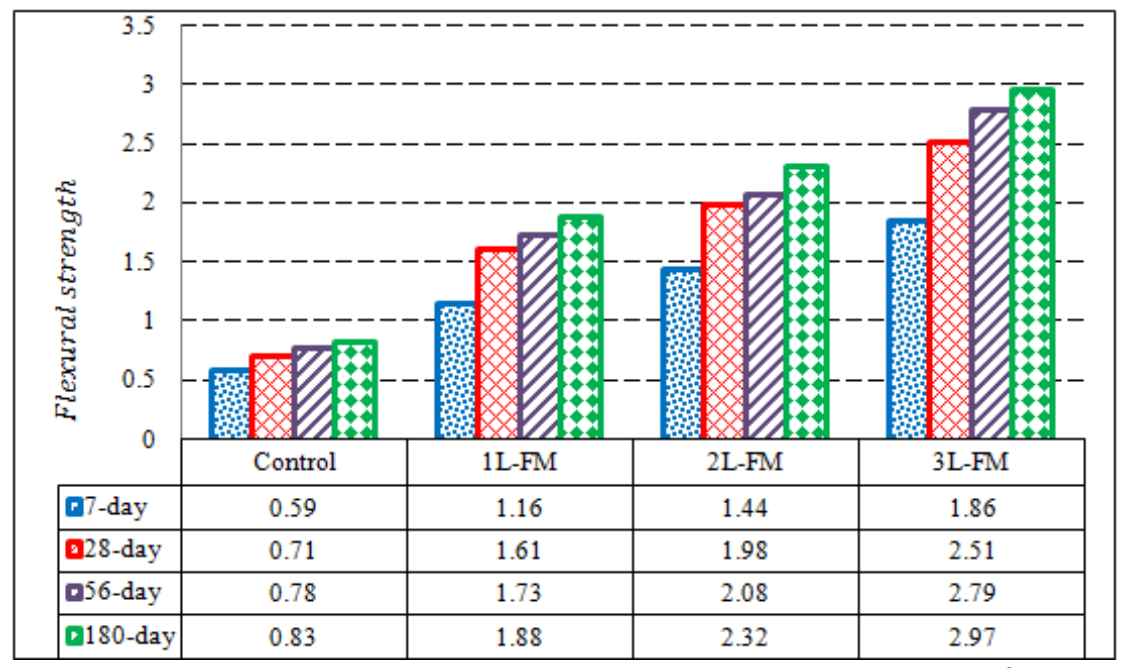

Figure 5: Flexural Strength of LFC Specimens with a Density of $1100 \mathrm{~kg} / \mathrm{m}^{3}$ Confined with Different Number of Layers of $160 \mathrm{~g} / \mathrm{m}^{2}$ of Woven Fiberglass Mesh.

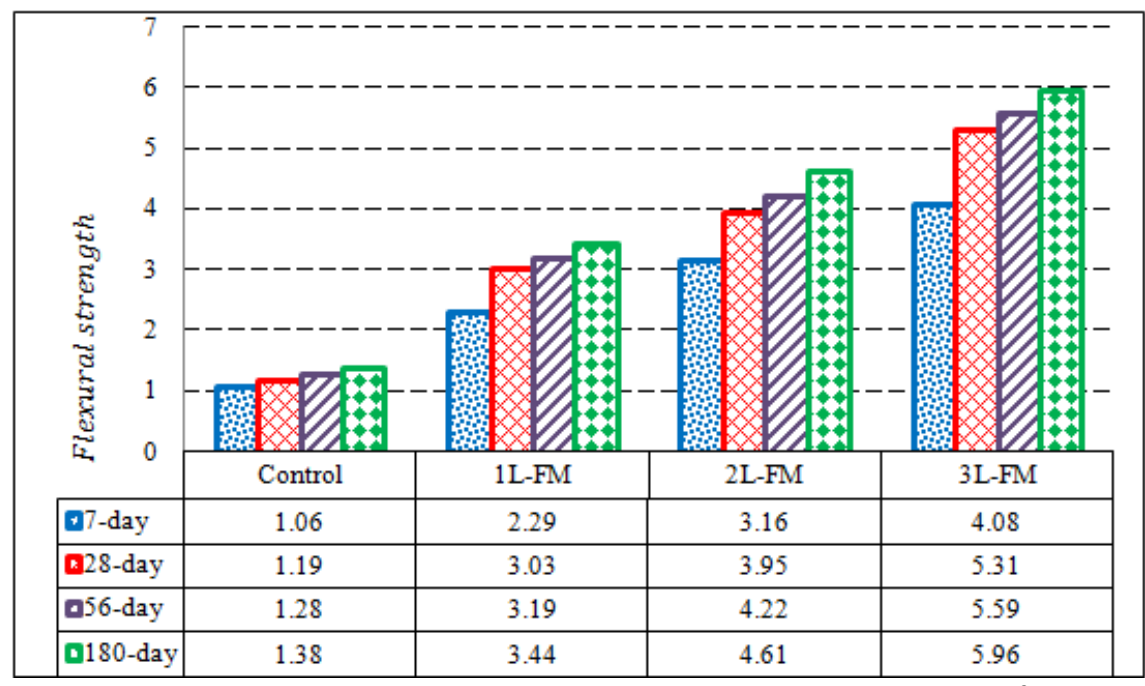

Figure 6: Flexural Strength of LFC Specimens with a Density of $1600 \mathrm{~kg} / \mathrm{m}^{3}$ Confined with Different Number of Layers of $160 \mathrm{~g} / \mathrm{m}^{2}$ of Woven Fiberglass Mesh. 
Table 2: Percentage Increase in Flexural Strength of LFC Specimens Confined with 1 Layer, 2 Layers, and 3 Layers of Woven Fiberglass Mesh at Three Different Densities Compared to the Control Specimens at Day-180

\begin{tabular}{|c|c|c|c|}
\hline \multirow{2}{*}{ Specimen } & \multicolumn{3}{|c|}{ Percentage increase (\%) } \\
\cline { 2 - 4 } & $\mathbf{6 0 0} \mathbf{~ k g} / \mathbf{m}^{\mathbf{3}}$ & $\mathbf{1 1 0 0} \mathbf{~ k g} / \mathbf{m}^{\mathbf{3}}$ & $\mathbf{1 6 0 0} \mathbf{~ k g} / \mathbf{m}^{\mathbf{3}}$ \\
\hline 1L-FM & 136 & 127 & 149 \\
\hline 2L-FM & 204 & 180 & 234 \\
\hline 3L-FM & 372 & 258 & 332 \\
\hline
\end{tabular}

\section{CONCLUSIONS}

From this study, the flexural strength increased as the density of LFC increased. The maximum flexural strength values obtained at the respective densities were $1.18 \mathrm{~N} / \mathrm{mm}^{2}, 2.97 \mathrm{~N} / \mathrm{mm}^{2}$, and $5.96 \mathrm{~N} / \mathrm{mm}^{2}$. The percentage increase in the flexural strength of LFC with different number of layers of woven fiberglass mesh compared to the control specimens was $136 \%$ to $372 \%$ for a density of $600 \mathrm{~kg} / \mathrm{m}^{3}, 127 \%$ to $258 \%$, and $149 \%$ to $332 \%$, for densities of $1100 \mathrm{~kg} / \mathrm{m}^{3}$ and $1600 \mathrm{~kg} / \mathrm{m}^{3}$, respectively. Therefore, this proved that the reinforcement of LFC with woven fiberglass mesh improved its flexural performance.

\section{REFERENCES}

1. Abdulameer, M. Z. (2015). Properties of Foamed Concrete With Oil Palm Ash Inclusion and Its Application As an Interlocking. Universiti Sains Malaysia.

2. Alberti, M. G., Enfedaque, A., \& Gálvez, J. C. (2014). On the mechanical properties and fracture behavior of polyolefin fiberreinforced self-compacting concrete. Construction and Building Materials, 55, 274-288. https://doi.org/10.1016/j.conbuildmat.2014.01.024

3. Amran, Y. H. M., Farzadnia, N., \& Ali, A. A. A. (2015). Properties and applications of foamed concrete; A review. Construction and Building Materials, 101(December), 990-1005. https://doi.org/10.1016/j.conbuildmat.2015.10.112

4. ASTM C348. (2004). Flexural strength of hydraulic-cement mortars. ASTM International, 04, 1-6.

5. Banthia, N., \& Sheng, J. (1996). Fracture toughness of micro-fiber reinforced cement composites. Cement and Concrete Composites, 18(4 SPEC. ISS.), 251-269. https://doi.org/10.1016/0958-9465(95)00030-5

6. Bentur, A., \& Mindess, S. (2007). Fibre Reinforced Cementitious Composites. In A. Bentur \& S. Mindess (Eds.), Taylor \& Francis (2nd Editio). https://doi.org/10.1016/0010-4361(79)90446-4

7. Bu, J., \& Tian, Z. (2016). Relationship between pore structure and compressive strength of concrete: Experiments and statistical modeling. Sadhana - Academy Proceedings in Engineering Sciences, 41(3), 337-344. https://doi.org/10.1007/s12046-016-0468-9

8. Chen, B., \& Liu, J. (2005). Contribution of hybrid fibers on the properties of the high-strength lightweight concrete having good workability. Cement and Concrete Research, 35(5), 913-917. https://doi.org/10.1016/j.cemconres.2004.07.035

9. Chi, H. L., \& Louda, P. (2019). Experimental Investigation of Four-Point Flexural Behavior of Textile Reinforcement in Geopolymer Mortar. International Journal of Engineering and Technology, 11(1), 10-15. https://doi.org/10.7763/ijet.2019.v11.1115

10. Chi, H. L., Louda, P., Van, S. L., Volesky, L., Kovacic, V., \& Bakalova, T. (2019). Composite Performance Evaluation of Basalt Textile-Reinforced Geopolymer Mortar. Fibers, 7(7), 63. https://doi.org/10.3390/fib7070063 
11. Dalal, M., Goumairi, O., \& Malik, A. El. (2017). Study of the internal confinement of concrete reinforced (in civil engineering) with woven reinforcement. IOP Conference Series: Materials Science and Engineering, 254(4). https://doi.org/10.1088/1757$899 X / 254 / 4 / 042008$

12. Dawood, E. T., \& Hamad, A. J. (2015). Toughness behaviour of high $\square$ performance lightweight foamed concrete reinforced with hybrid fibres. Structure Concrete, 16(4), 496-507. https://doi.org/https://doi.org/10.1002/suco.201400087

13. Falliano, D., De Domenico, D., Ricciardi, G., \& Gugliandolo, E. (2019). Compressive and flexural strength of fiber-reinforced foamed concrete: Effect of fiber content, curing conditions and dry density. Construction and Building Materials, 198, 479493. https://doi.org/10.1016/j.conbuildmat.2018.11.197

14. Gandhi Mallela, PallaviPaturu, and M. Komaleswarao. "Lift and drag performance of NACA0012 airfoil at various angle of attack using CFD." International journals of mechanical and production engineering research and development 8.3 (2018): 89-100.

15. Gayathri, C. N., Singh, R. B., \& Dhanalakshmi, G. (2018). Mechanical behaviour of textile reinforced concrete. International Research Journal of Engineering and Technology (IRJET), 5(5), 2227-2231. Retrieved from https://www.academia.edu/38216913/IRJET__Mechanical_Behaviour_of_Textile_Reinforced_Concrete

16. Gencoglu, M., \& Mobasher, B. (2007). Static and Impact Behaviour of Fabric Reinforced Composites in Flexure. In H. W. Reinhardt \& A. E. Naaman (Eds.), Fifth International RILEM Workshop on High Performance Fiber Reinforced Cement Composites (HPFRCC5) (pp. 463-470).

17. Ibrahim, M. H. W., Jamaludin, N., Irwan, J. M., Ramadhansyah, P. J., \& Hani, A. S. (2014). Compressive and flexural strength of foamed concrete containing polyolefin fibers. Advanced Materials Research, 911(March), $489-493$. https://doi.org/10.4028/www.scientific.net/AMR.911.489

18. Jones, M. R., \& McCarthy, A. (2005). Preliminary views on the potential of foamed concrete as a structural material. Magazine of Concrete Research, 57(1), 21-31. https://doi.org/10.1680/macr.2005.57.1.21

19. Kayali, O., Haque, M. N., \& Zhu, B. (2003). Some characteristics of high strength fiber reinforced lightweight aggregate concrete. Cement and Concrete Composites, 25(2), 207-213. https://doi.org/10.1016/S0958-9465(02)00016-1

20. Kozłowski, M., \& Kadela, M. (2018). Mechanical Characterization of Lightweight Foamed Concrete. Advances in Materials Science and Engineering, 2018, 1-8. https://doi.org/10.1155/2018/6801258

21. Khan, Saleem Anwar, et al. "Thermal and solutal buoyancy effects on mixing of opposed laminar jets in a two-dimensional passive mixer at a higher Reynolds number." Int. J. Mech. Prod. Eng. Res. Dev. 9.3 (2019): 923-930.

22. Lian, C., Zhuge, Y., \& Beecham, S. (2011). The relationship between porosity and strength for porous concrete. Construction and Building Materials, 25, 4294-4298. https://doi.org/10.1016/j.conbuildmat.2011.05.005

23. Min, Kyoung-Moo, Foong-Yi Chia, and Bong-Hwan Kim. "Design and CFD Analysis of a Low-Altitude VTOL UAV."International Journal of Mechanical and Production Engineering Research and Development (IJMPERD) 9.2, Apr 2019, 555-562

24. Naaman, A. E. (2010). Textile Reinforced Cement Composites: Competitive status and research directions. International RILEM Conference on Material Science, I, 3-22. Retrieved from https://www.rilem.net/images/publis/pro075-001.pdf

25. Narayanan, N., \& Ramamurthy, K. (2000). Structure and properties of aerated concrete: A review. Cement and Concrete Composites, 22(5), 321-329. https://doi.org/10.1016/S0958-9465(00)00016-0 
26. Olaoye, R. A., Oluremi, J. R., \& Ajamu, S. O. (2013). The Use of Fibre Waste as Complement in Concrete for a Sustainable Environment. Innovative Systems Design and Engineering, 4(9), 91-98. Retrieved from https://s3.amazonaws.com/academia.edu.documents/31489800/The_Use_of_Fibre_Waste_as_Complement_in_Concrete_for_ a_Sustainable_Environment.pdf?response-content-disposition=inline $\% 3 B$ filename\%3DIISTE_journals_June_30th_Publications.pdf\&X-Amz-Algorithm=AWS4-HM

27. Peled, A., Bentur, A., \& Yankelevsky, D. (1999). Flexural Performance of Cementitious Composites Reinforced with Woven Fabrics. Journal of Materials in Civil Engineering, 11(4), 325-330. Retrieved from https://ascelibrary.org/doi/pdf/10.1061/\%28ASCE\%290899-1561\%281999\%2911\%3A4\%28325\%29

28. Reddy, G. V., Naidu, S. V., \& Rani, T. S. (2008). Kapok/glass polyester hybrid composites: Tensile and hardness properties. Journal of Reinforced Plastics and Composites, 27(16-17), 1775-1787. https://doi.org/10.1177/0731684407087620

29. Salimian, A., Hadizadeh, M., \& Zeini, M. (2016). Investigations on the Reinforcement of Mechanical Properties of Gypsum Composites Containing E-glass Woven Fabrics. Journal of Textiles and Polymers, 4(1), 20-26. Retrieved from http://www.itast.ir/article_13886_9d8a5a4b94166c61b71586275c42de9d.pdf

30. Vogel, F., Holcapek, O., \& Konvalinka, P. (2016). Response of high-performance fibre reinforced concrete reinforced by textile reinforcement to impact loading. Acta Polytechnica, 56(4), 328-335. https://doi.org/10.14311/AP.2016.56.0328

31. Wei, J., \& Meyer, C. (2016). Utilization of rice husk ash in green natural fiber-reinforced cement composites: Mitigating degradation of sisal fiber. Cement and Concrete Research, 81, 94-111. https://doi.org/10.1016/j.cemconres.2015.12.001

32. Wong, K. J., Nirmal, U., \& Lim, B. K. (2010). Impact behavior of short and continuous fiber-reinforced polyester composites. Journal of Reinforced Plastics and Composites, 29(23), 3463-3474. https://doi.org/10.1177/0731684410375639

33. Wilson, Erin, and Nivin Philip. "The Influence of Fibres in Concrete: A Review." International Journal of Civil Engineering (IJCE) 4.6 (2015): 1-10. 

